\title{
Development of a Cotton Smart Textile with Medicinal Properties Using Lime Oil Microcapsules
}

\author{
Piyumi B. Wijesirigunawardana and B. Gayani K. Perera ${ }^{\star}$ \\ Department of Chemistry, University of Colombo, Colombo 03, Sri Lanka \\ *Corresponding author: E-mail: gayani@sci.cmb.ac.lk
}

Received: 01-08-2017

\begin{abstract}
The present study focused on using microencapsulation technique to develop an antioxidant and antibacterial active smart cotton fabric using encapsulated lime oil (LO). LO microcapsules were prepared via the complex coacervation method using chitosan and gum arabic wall materials. UV-Visible and FTIR spectrometry verified the successful encapsulation of LO. The synthesized LO microcapsules were irregular in shape and differed in size between $15-160 \mu \mathrm{m}$ according to the optical and SEM images. The loading of the microcapsules was found to be $2943 \pm 128 \mu \mathrm{L} / \mathrm{g}$ with a loading efficiency of $82 \pm 4 \%$. The antioxidant activity of the LO microcapsules was $1336 \pm 17 \mu \mathrm{g}$ PGE/g (Folin-Ciocalteu assay). Brine shrimp lethality assay indicated that the cytotoxicity of LO was minimized upon microencapsulation. Succinic acid was used as the binder to incorporate the LO microcapsules on to the cotton fabric. The SEM images confirmed the steady attachment of LO microcapsules to the cotton fibres. The cotton fabric containing LO microcapsules displayed significant antibacterial activity against four bacterial species prior to and after subjecting the fabric to wash conditions.
\end{abstract}

Keywords: Smart textiles, Microencapsulation, Lime oil, Antioxidant, Antibacterial

\section{Introduction}

The enhancement of the quality and standards of life styles of people expands with the gradual improvement of the medicinal and technological knowledge. This in turn leads to the emergence of innovative and value-added products related to health and beauty. ${ }^{1}$ The textile industry has nowadays become more competitive due to the production of active, multifunctional and interactive smart textiles. ${ }^{2}$ Smart textiles are also known as intelligent textiles and these are produced by introducing various useful properties to the fibres of the fabric. ${ }^{2}$ A textile becomes more attentive to consumers when it starts to exhibit useful properties, especially when it is in contact with the human body. Thus, smart technology has contributed towards solving numerous problems in the textile industry that cannot be addressed by traditional textile processing. ${ }^{1,3,4}$

Microencapsulation has been a useful technique since 1990 s to produce smart textile materials. ${ }^{5}$ Microencapsulation is a micro packaging technique which produces microcapsules containing a desired encapsulated active material. The size of the microcapsule vary between 1 to $1000 \mu \mathrm{m} .{ }^{1,6,7}$ Therefore, microencapsulation can be defined as the process of coating of small solid particles or liquid droplets or dispersions of solid particles with a continuous film. ${ }^{1,8}$ The method of microencapsulation can be chosen according to the properties of its core and coating materials and the user requirements of the final product. ${ }^{15,5,8}$ The core material is also called the internal phase, encapsulate, payload or the fill. ${ }^{1,5}$ The core content of the microcapsules may be released to the exterior in a controlled manner by friction, pressure, change of temperature, diffusion through the polymer wall, dissolution of the polymer wall coating or by biodegradation. ${ }^{5}$ The polymer coating surrounding the active ingredient or the encapsulated material in microcapsules is also called the wall, shell, external phase, membrane or matrix. The nature of the wall material can be natural, semi-synthetic or synthetic and it must be capable of forming a non-reactive cohesive film around the core material. ${ }^{1,6,9}$ The wall material helps to determine the strength, flexibility, permeability, optical properties and stability of the microcapsules. ${ }^{1,5}$

Microencapsulation provides a range of advantages to the encapsulated core material. These include protection of active ingredients against heat, light, acidity, alkalinity, moisture and oxidation as well as the controlled release of the encapsulated material. Furthermore, microencapsulation enables to disguise the unpleasant flavors or odors of the core materials and also allows the easy han- 
dling of core materials due to the powder-like nature of the final microcapsulated product. ${ }^{1,5,9}$

Among the wide range of microencapsulation methods in use, the most often used ones in the textile industry are the coacervation and interfacial polymerization methods. ${ }^{7}$ During this research, complex coacervation method was selected to synthesize lime oil microcapsules, using gum arabic and chitosan as the wall materials. During complex coacervation method, a polymer rich wall material is deposited around the core material. ${ }^{5,10} \mathrm{~A}$ wide variety of natural materials such as gelatin, agar, gum, sodium alginate, calcium alginate, dextran, fat and fatty acid starch, chitosan, casemate, sucrose, and wax can be used as the wall material during complex coacervation. ${ }^{1}$

Nowadays, more commercial applications of microencapsulation can be found in the textile industry because of its capability of being adjusted for different tasks. ${ }^{5}$ The microencapsulation technique is used to develop and modify textiles with new enhanced properties such as polychromic and thermochromic textiles, fire proofing textiles, fragrance releasing textiles, cosmetic textiles, therapeutic textiles and medical textiles. ${ }^{5,7}$

The cooperation between the medical profession and the textile industry has successfully resulted in the development of bio-medical smart textiles that fulfill a specific market niche and thereby providing bioactive body care to understand and satisfy the consumer needs and physiological conditions of the human skin. ${ }^{5}$ For an example, microencapsulation technique has led the textile industry to produce medicinal fabrics with durable fragrances that are useful in aromatherapy. ${ }^{11,12}$ Microcapsules are synthesized in aromatherapy using essential oils such as lavender, almond, jasmine, sassafras, myrrh, rosemary, lime and pine. ${ }^{2,8}$ Such microcapsules are often used to treat health conditions such as insomnia, headache, and to prevent bad odor. ${ }^{12}$ However, the direct application of fragrances to fibers failed to survive for a significant time period or few wash cycles due to the volatility of all fragrances. ${ }^{12,13}$ The present study was mainly focused on the microencapsulation of lime essential oil and development of a medicinal smart textile using the synthesized lime oil microcapsules that provides medicinal properties upon releasing of the active core ingredients to the exterior under controlled conditions. Lime essential oil is one of the most reasonably priced and best therapeutic essential oils. Pure lime oil is a mixture of volatile compounds obtained by mechanically rupturing or cold pressing the peel of the fruit of lime tree (Citrus aurantifolia). $.^{14,15,16} \mathrm{Cit}-$ ric essential oils are commonly composed of terpenes such as $\alpha$-thujene, $\alpha$-pinene, camphene, sabinene, $\beta$-pinene, myrcene, $\alpha$-terpinene, $p$-cymene, linalool, and d-limonene. ${ }^{18}$ Lime oil is a powerful healing agent of acne, asthma, colds, dull skin, flu and sore throats. It also displays other beneficial properties such as antiseptic, antioxidant, antiviral, antiinflammatory, antinitrosaminic, astringent, aperitif, bactericide, antitumor and disinfec- tant activities. Furthermore, lime oil is also known for its hypocholesterinemic, cardiotonic, sedative and stomachic activities ${ }^{15,16,18}$

In order to characterize the synthesized lime oil microcapsules, optical and scanning electron microscopic images, UV-Visible and FT-IR spectra, anti-oxidant assays, anti-bacterial assays and cytotoxicity assay were carried out. After the characterization of synthesized lime oil microcapsules, the main focus of this research was to successfully apply the lime oil microcapsules on to a cotton fabric using succinic acid as the binder. ${ }^{19}$

\section{Experimental}

\section{1. Preparation of Lime Oil Microcapsules by Complex Coacervation Method}

A portion of $2.5 \mathrm{~g}$ of gum arabic was mixed with $50 \mathrm{~mL}$ of distilled water and the mixture was stirred at $50{ }^{\circ} \mathrm{C}$ for about 20 minutes until all the gum arabic was completely dissolved. The mixture was kept at room temperature. A mixture of $1.0 \mathrm{~g}$ of chitosan, $50 \mathrm{~mL}$ of distilled water and $4.0 \mathrm{~mL}$ of pure lime oil was stirred at $600 \mathrm{rpm}$ for about 10 minutes at room temperature until an emulsion was obtained. While stirring, the prepared emulsion was added dropwise into the gum arabic solution kept in an ice bath. The mixture was stirred continuously for another hour. Prepared lime oil microcapsules were well washed with a $70 \%$ ethanol solution to remove any remaining unencapsulated oil. The removal of the unencapsulated oil was monitored by using the UV-Visible spectra of each wash. The washed capsules were gravity filtered and dried inside a desiccator. The microcapsules were kept in refrigerator until further use. ${ }^{20}$

\section{2. Verification of Lime Oil Microencapsulation}

A portion of $0.08 \mathrm{~g}$ of washed microcapsules was transferred into a falcon tube containing $2.0 \mathrm{~mL}$ of $70 \%$ ethanol. Another $0.08 \mathrm{~g}$ of washed microcapsules was transferred into another falcon tube containing $2.0 \mathrm{~mL}$ of $70 \%$ ethanol and it was well crushed using a glass rod, followed by sonication for 15 minutes. Both samples were centrifuged at $4000 \mathrm{rpm}$ for 10 minutes. The supernatants were collected separately. UV-Visible spectra of the supernatants and pure lime oil were obtained and the spectra were compared. The absorbance values of both intact (uncrushed) and crushed microcapsule samples at $243 \mathrm{~nm}$ were recorded (the wavelength at which the maximum absorbance for pure lime oil was observed) and compared. A mixture of gum arabic, chitosan and 70\% ethanol was used as the blank for the UV-Visible spectroscopic experiments. FT-IR spectra were also obtained to verify the encapsulation of lime oil in microcapsules. 


\section{3. Investigation of the Morphology of Microcapsules}

The prepared lime oil microcapsules were observed under the optical and scanning electron microscopes.

\section{4. Determination of the Loading and Loading Efficiency of Lime Oil Microcapsules}

A concentration series was prepared by dissolving pure lime oil in $70 \%$ ethanol. The absorbance of the standard series was measured at $243 \mathrm{~nm}$ and a standard curve was developed. A portion of $0.05 \mathrm{~g}$ washed microcapsules was transferred into an eppendorf tube. The microcapsules were well crushed mechanically and $1 \mathrm{~mL}$ of $70 \%$ ethanol was added. The sample was sonicated for about $15 \mathrm{~min}$ utes. The crushed sample was centrifuged $4000 \mathrm{rpm}$ for 10 minutes. The absorbance of the supernatant was measured at $243 \mathrm{~nm}$. Loading of lime oil microcapsules was calculated by using the standard curve. Loading efficiency of the microcapsules was calculated using the following equation (1). The experiment was carried out in triplicate. ${ }^{21,22}$

$$
\begin{aligned}
& \text { Loading efficiency }(\%)= \\
& =\frac{\text { Volume of encapsulated lime oil in microcapsules }}{\text { Volume of total lime oil used }} \times 100
\end{aligned}
$$

\section{5. Folin Ciocalteu Assay}

\section{5. 1. Preparation of the Folin Ciocalteu Reagent}

A portion of $10.0 \mathrm{~g}$ of sodium tunstate and $2.5 \mathrm{~g}$ of sodium molybdate were dissolved in $70.0 \mathrm{~mL}$ of distilled water in a round bottom flask. A volume of $5.0 \mathrm{~mL}$ of $85 \%$ of $\mathrm{H}_{3} \mathrm{PO}_{4}$ acid and $10.0 \mathrm{~mL}$ of concentrated $\mathrm{HCl}$ were added into the round bottom flask. The mixture was refluxed for 10 hours inside a fume hood. Portion of $15.0 \mathrm{~g}$ of lithium sulphate, a volume of $5.0 \mathrm{~mL}$ of distilled water and one drop of liquid bromine were added. The mixture was refluxd for another 15 minutes. The mixture was allowed to cool at room temperature and finally the volume was adjusted to $100.0 \mathrm{~mL}$ with distilled water. ${ }^{24}$

\section{5. 2. Folin-Ciocalteu Assay Procedure}

A standard series was prepared using pyrogallol in methanol. A volume of $2.0 \mathrm{~mL}$ of $2 \%(\mathrm{w} / \mathrm{v})$ sodium bicarbonate was mixed with $100 \mu \mathrm{L}$ of each standard solution. The samples were incubated for 2 minutes. A volume of $100 \mu \mathrm{L}$ of Folin Ciocalteu reagent was added to each sample. The samples were incubated for 30 minutes in the dark. The absorbance of each sample was measured at $750 \mathrm{~nm}$ using the UV-Visible spectrophotometer. The standard curve was developed. The same procedure was carried out with $0.04 \mathrm{~g} / \mathrm{mL}$ methanolic solutions of crushed and uncrushed microcapsules and pure lime oil (an equivalent amount to that encapsulated in microcap- sules). The antioxidant activity of the test samples was determined using the standard curve. The experiment was carried out in triplicate. ${ }^{23,24}$

\section{6. Brine Shrimp Lethality Assay to Test the Cytotoxic Activity of Lime Oil Microcapsules}

Brine shrimp eggs were hatched using 3.8\% $\mathrm{NaCl}$ solution inside a glass container. Ten nauplii were transferred into a $5 \mathrm{~mL}$ solution of $3.8 \% \mathrm{NaCl}$. An aliquot of $50 \mu \mathrm{L}$ of an ethanolic solution containing crushed or uncrushed microcapsules (prepared by mixing $0.08 \mathrm{~g}$ of crushed or uncrushed microcapsules in $1.0 \mathrm{~mL}$ of $70 \%$ ethanol) or pure lime oil (an equivalent amount to the encapsulated amount in microcapsules) was added. A $50 \mu \mathrm{L}$ aliquot of $70 \%$ of ethanol was used as the negative control. Each sample was observed for a period of 8 hours and the numbers of live and dead nauplii were recorded after each hour. The experiment was carried out in triplicate and the percentage mortality was calculated for each experiment using the following equation (2). ${ }^{23}$

$$
\begin{aligned}
& \text { Percentage mortality }(\%)= \\
& =\frac{\text { no.of dead brine shrimp naupilii }}{\text { Total no.of brine shrimp nauplii }} \times 100
\end{aligned}
$$

\section{7. Antibacterial Activity of Lime Oil Microcapsules}

Antibacterial activity of crushed, uncrushed and unencapsulated lime oil (a similar equivalent to the amount encapsulated in the crushed microcapsule sample) was tested against Escherichia coli (ATCC 35218), Bacillus cereus (ATCC 11778), Salmonella typhimurium (ATCC 14028), and Staphylococcus aureus (ATCC 25923) using the disk diffusion assay according to previously published protocols. ${ }^{15,23}$

\section{8. Incorporation of Lime Oil Microcapsules Into Cotton Fabric}

A portion of $0.3 \mathrm{~g}$ of microcapsules was mixed with $3.0 \mathrm{~mL}$ saturated succinic acid. The sample was stirred overnight. Microcapsules were filtered and resuspended in $1 \mathrm{~mL}$ of distilled water. A piece of $5 \times 5 \mathrm{~cm}^{2}$ cotton cloth was dipped in the aqueous solution of microcapsules. The cloth was air dried and ironed. Antibacterial activity of the microcapsule incorporated cotton fabric was investigated and the SEM images of the same fabric were taken.

To investigate the wash fastness of the microcapsules incorporated fabric, a piece of $5 \times 5 \mathrm{~cm}^{2}$ microcapsule incorporated cotton fabric was stirred at $500 \mathrm{rpm}$ for $30 \mathrm{~min}$. Cloth disks were cut from the washed cloth and the disks were mechanically crushed to break the attached microcapsules. Antibacterial activity of the microcapsule incor- 
porated washed cotton fabric was investigated and the SEM images were also taken of the same cloth.

\section{Results and Discussion}

\section{1. Verification of Lime Oil Microencapsulation}

UV-Visible spectra of crushed and uncrushed lime oil microcapsules were used to verify the lime oil encapsulation in microcapsules.

Table 1. UV absorbance of uncrushed and crushed lime oil microcapsules at $243 \mathrm{~nm}$ wave length

\section{Test sample}

UV absorbance at $243 \mathrm{~nm}$

Uncrushed lime oil microcapsules

Crushed lime oil microcapsules
No absorbance $3.267 \pm 0.1$
According to the results shown in Table 1, it was observed that the mechanically crushed microcapsules recorded a significantly higher UV absorbance value at $243 \mathrm{~nm}$ wavelength compared to the uncrushed microcapsules. Therefore, it can be concluded that lime oil was successfully encapsulated in the prepared microcapsules and the encapsulated oil can be released upon mechanical crushing of the microcapsule wall.

FT-IR spectra were also obtained for unencapsulated lime oil, the crushed microcapsules (Figures $1 \& 2$ ), chitosan and gum arabic (Figures $3 \& 4$ ) to verify the encapsulation of lime oil.

Similar absorption peaks at characteristic wavelength number were the indication of similar functional groups in crushed microcapsules, unencapsulated lime oil, gum arabic and chitosan spectra. A broad characteristic peak can be observed at 3400 approximately in four spectra. That was an indication of the presence of $-\mathrm{OH}$ functional group in all four samples. This functionality can be seen in linalool present in lime oil as well as in gum arabic

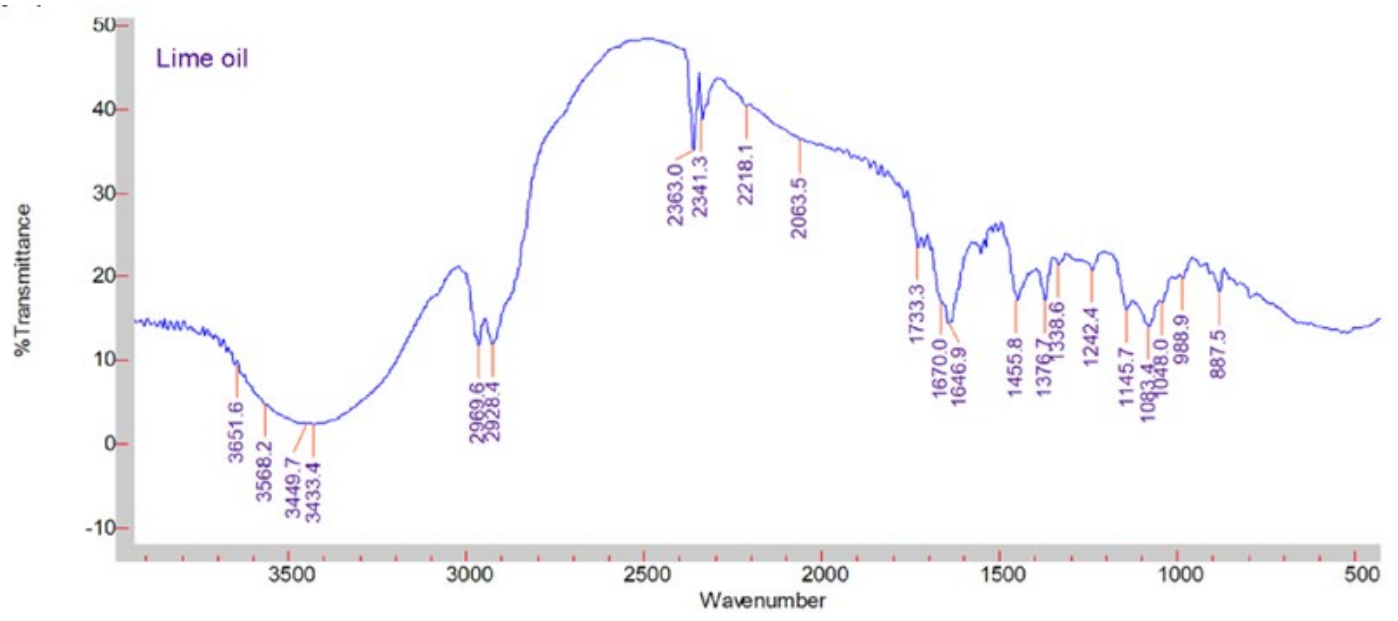

Figure 1. FT-IR spectrum of unencapsulated lime oil

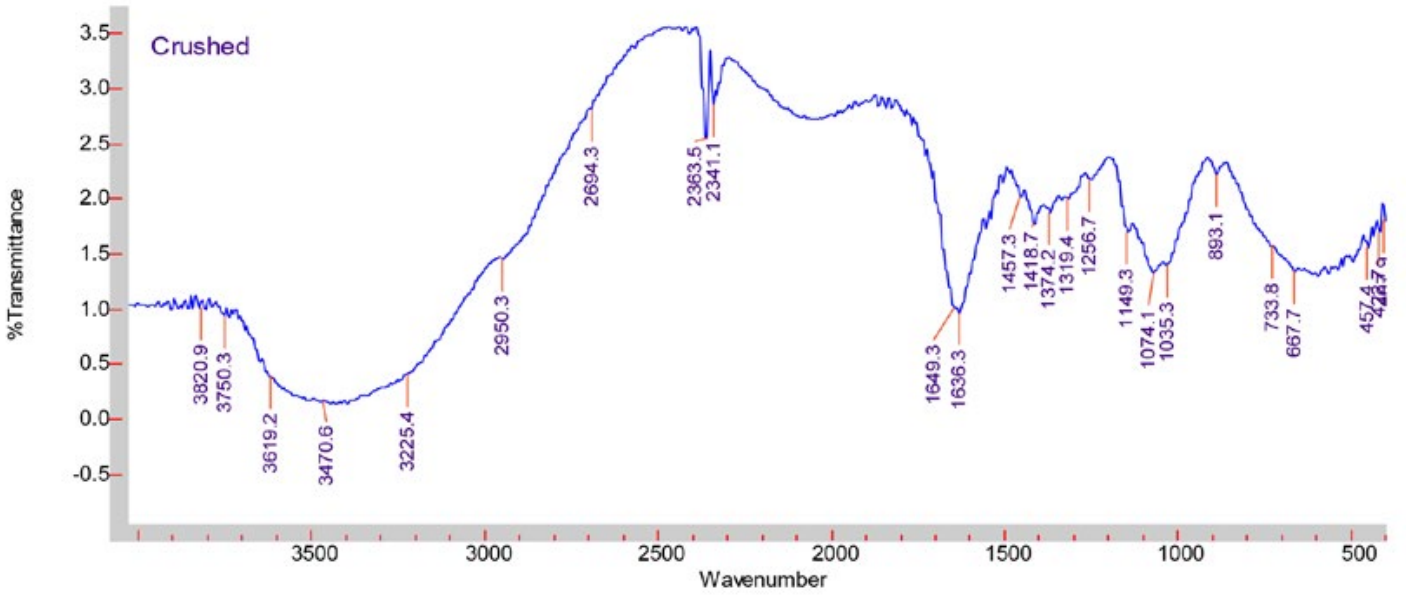

Figure 2. FT-IR spectrum of crushed microcapsules 


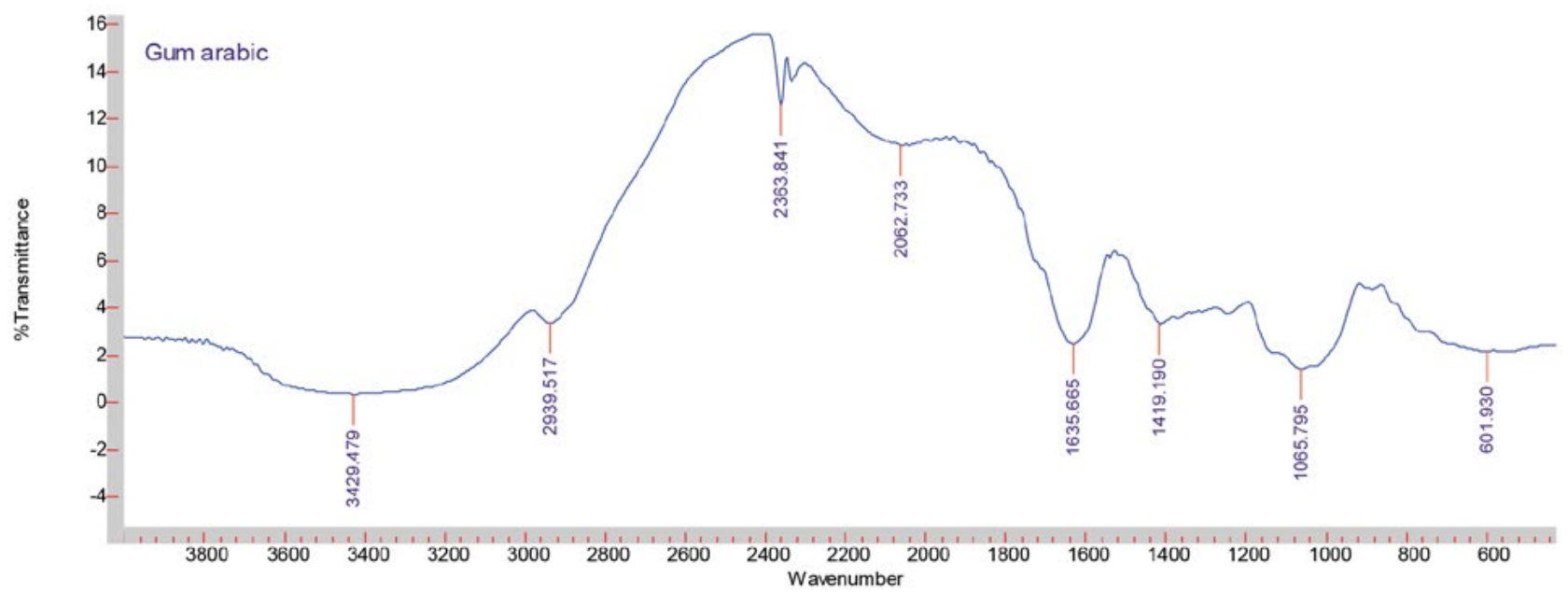

Figure 3. FT-IR spectrum of gum arabic

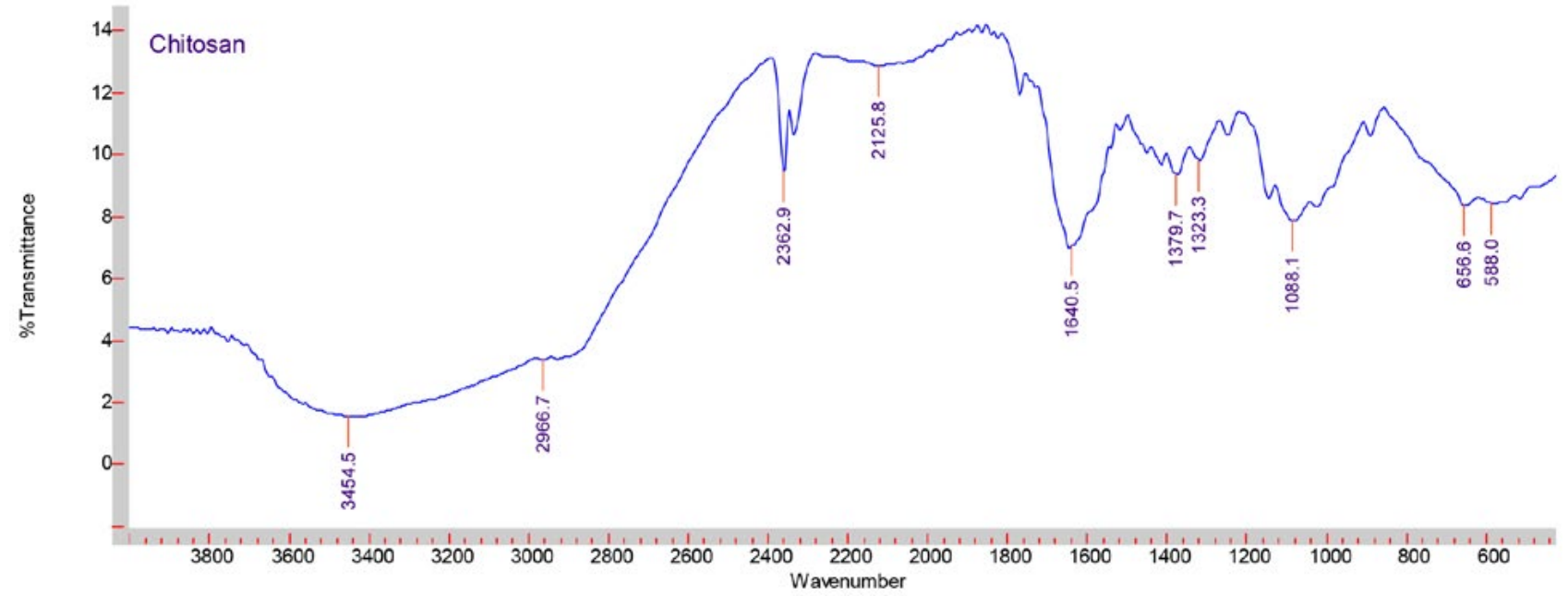

Figure 4. FT-IR spectrum of chitosan

and chitosan. There was an absorption $\mathrm{W}$ shaped peak around at 2950 in the unencapsulated lime oil spectrum. It was an indication of the presence of alkalyl - $\mathrm{CH}$ bonds. This functionality can be seen in limonene which is one of the major constituents of lime oil. The peak that was observed in unencapsulated lime oil and crushed microcapsule spectra around 1650 may be an indication of the presence of a conjugated carbonyl group. This functionality can be seen in citral present in lime oil. Thus, according to the IR data, it can be suggested that lime oil has been successfully encapsulated.

\section{2. Investigation of the Morphology of Lime Microcapsules}

The morphological characterization of the resultant lime oil microcapsules was carried out using the optical microscope (Figure 5) and the scanning electron microscope (Figure 6).

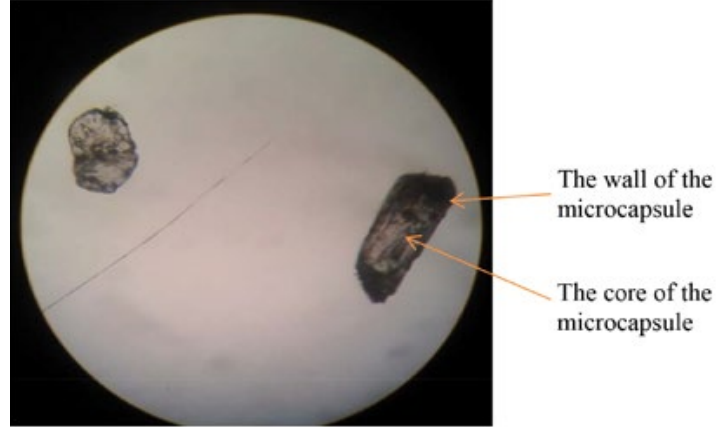

Figure 5. An optical microscopic image of lime oil microcapsules ( $\times$ 100 magnification)

According to microscopic images, it can be suggested that the resultant lime oil microcapsules were irregular in shape and their sizes ranged between 15-300 $\mu \mathrm{m}$. The SEM images indicated that the synthesized microcapsules were composed of rough walls. 

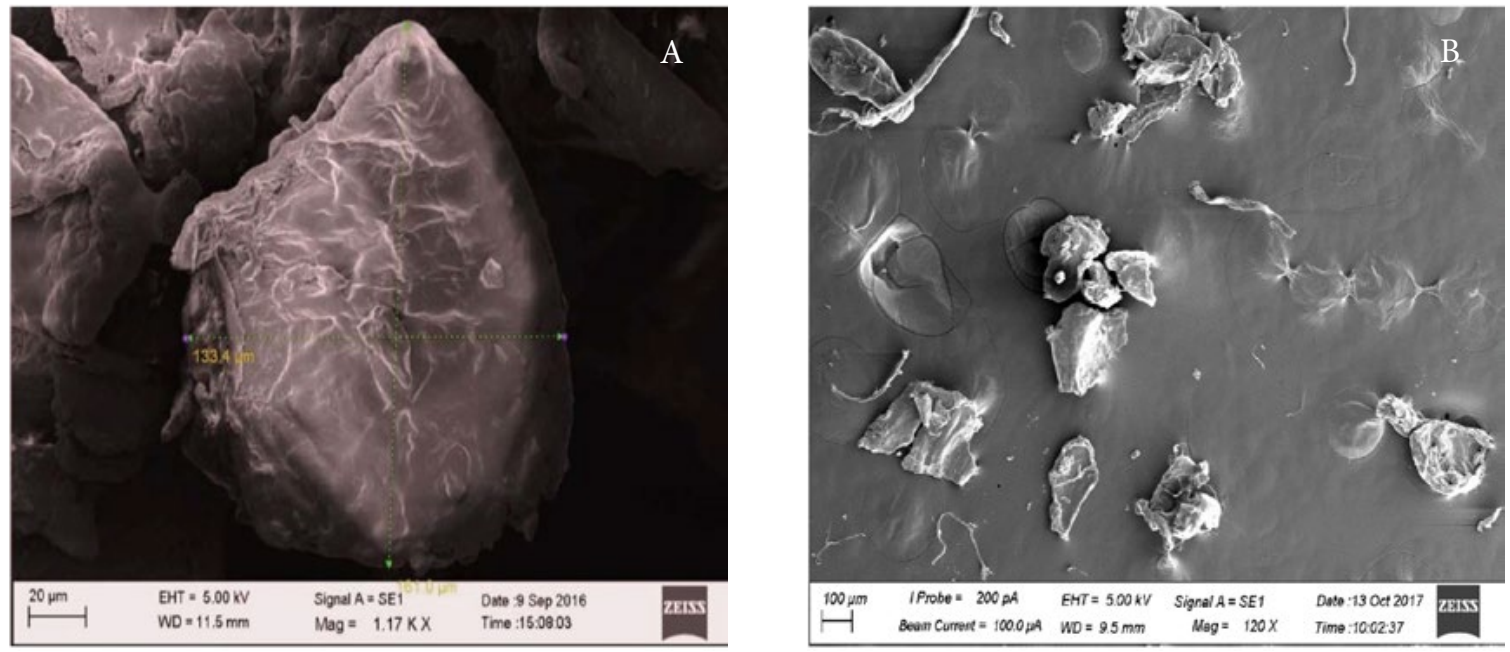

Figure 6. A - The scanning electron microscopic image of lime oil microcapsule $(\times 1.17 \mathrm{~K}$ magnification $) \mathrm{B}-$ The scanning electron microscopic image of lime oil microcapsules ( $\times 120$ magnification)

\section{3. Determination of the Loading and Loading Efficiency of Lime Oil Microcapsules}

The loading efficiency signifies the fraction of lime oil incorporated into microcapsules compared to the total volume of lime used to synthesize the microcapsules. The loading of the lime oil microcapsules was found to be 2940 $\pm 138 \mu \mathrm{L} / \mathrm{g}$ and the loading efficiency was found to be $82 \pm$ $4 \%$.

\section{4 Folin Ciocalteu Assay}

Folin Ciocalteu reagent has the ability to react with a wide range of anti-oxidants present in the test sample.
The results of the Folin Ciocalteu assay are shown below in Table 2.

According to the results in Table 2, it can be concluded that the AOC of lime oil was retained after the encapsulation process. However, the AOC of crushed microcapsules was higher than that resulted from a similar amount

Table 2. Antioxidant capacity (AOC) of unencapsulated lime oil and lime oil microcapsules

\begin{tabular}{cc}
\hline Test sample & AOC $(\boldsymbol{\mu g}$ PGE $/ \mathbf{g})$ \\
\hline Unencapsulated lime oil $^{\star}$ & $916 \pm 8$ \\
Crushed microcapsules & $1336 \pm 17$ \\
\hline
\end{tabular}

* An equivalent amount of lime oil to that in the crushed microcapsules sample

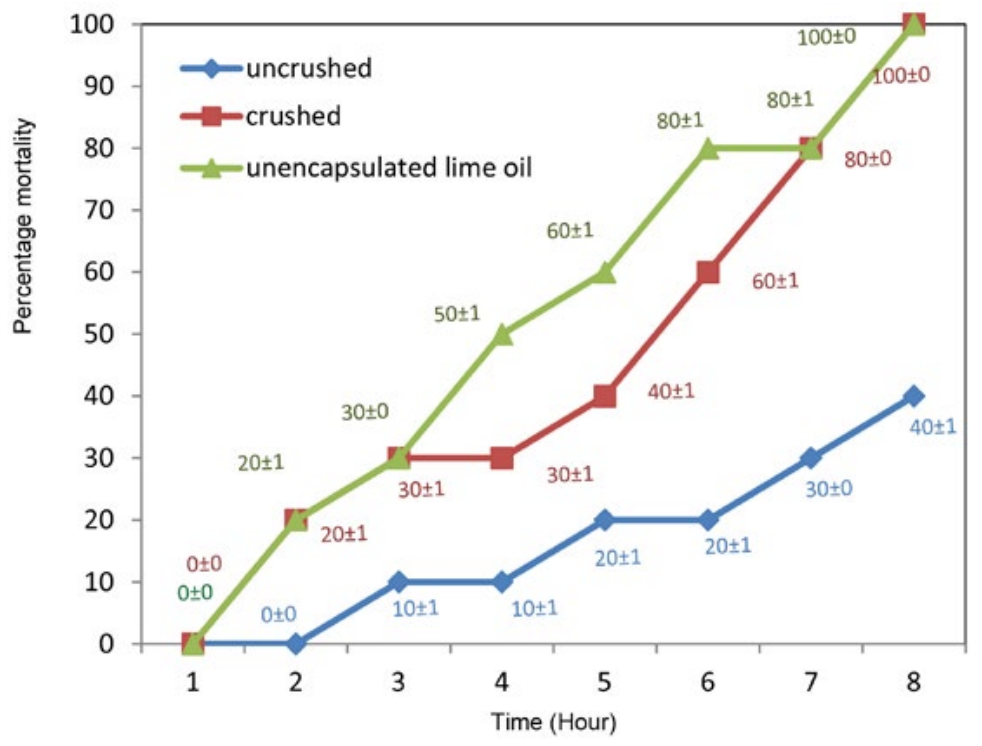

Figure 7. Percentage mortality of shrimp nauplii against time for different lime oil samples 
of unencapsulated lime oil. It has been reported that chitosan is an anti-oxidant agent. ${ }^{25,26}$ Therefore, it can be concluded that the extra AOC could be due to the chitosan wall material used to synthesize the lime oil microcapsules.

\section{5. Brine Shrimp Lethality Assay to Test the Cytotoxicity of Lime Oil Microcapsules}

The brine shrimp leathality assay carried out with Artemia salina naupilii can be used to monitor the cytotoxic activity of unencapaulated and encapsulated lime oil. ${ }^{27}$ The results of the brine shrimp lethality assay are shown in Figure 7.

According to the results, it can be concluded that the brine shrimp lethality was minimized when lime oil was encapsulated compared to the direct use of lime oil.

\section{6. Antibacterial Activity of Lime Oil Microcapsules}

The results of the antibacterial studies are shown in Table 3.
Unencapsulated lime oil resulted in inhibition zones for all four tested bacterial strains. Similarly, the crushed microcapsules displayed inhibition zones against all the bacterial strains. However, intact microcapsules did not show inhibition zones against any of the four strains. Therefore, it can be concluded that the encapsulated lime oil was released upon mechanical crushing and displayed similar antibacterial activity as the unencapsulated lime oil.

\section{7. Incorporation of Lime Oil Microcapsules Into Cotton Fabric}

Lime oil microcapsules were incorporated into a cotton fabric using succinic acid as the binder. Cotton is composed of cellulose which is the most commonly used natural polymer and it can be chemically modified at the hydroxyl groups that enable the esterification with succinic acid which helps in the attachment of microcapsules to the cotton fabric upon ironing. This is possible as cellulose esters are formed upon heating. ${ }^{19} \mathrm{~A}$ saturated solution of succinic acid was used to dip the microcapsules. These microcapsules were then filtered and used to prepare an

Table 3. Diameter of the inhibition zones for bacterial species with different lime oil samples

\begin{tabular}{lcccc}
\hline Sample & \multicolumn{3}{c}{ Diameter of the inhibition zone (mm) } \\
& E.coli & B.cereus & S.typhimurium & S.aureus \\
\hline Positive control $(25 \mu \mathrm{L} / \mathrm{mL}$ Gentamicin) & $24 \pm 0$ & $23 \pm 1$ & $24 \pm 0$ & $24 \pm 1$ \\
Negative control $(70 \%$ ethanol) & $\mathrm{NI}$ & $\mathrm{NI}$ & $\mathrm{NI}$ & $\mathrm{NI}$ \\
Unencapsulated lime oil $^{\star}$ & $8 \pm 0$ & $8 \pm 1$ & $7 \pm 0$ & $8 \pm 1$ \\
Crushed lime oil microcapsules & $8 \pm 0$ & $8 \pm 1$ & $7 \pm 0$ & $7 \pm 1$ \\
Intact lime oil microcapsules & $\mathrm{NI}$ & $\mathrm{NI}$ & $\mathrm{NI}$ & $\mathrm{NI}$
\end{tabular}

* An equivalent amount of lime oil to that encapsulated in the crushed microcapsules. NI $=$ No inhibition
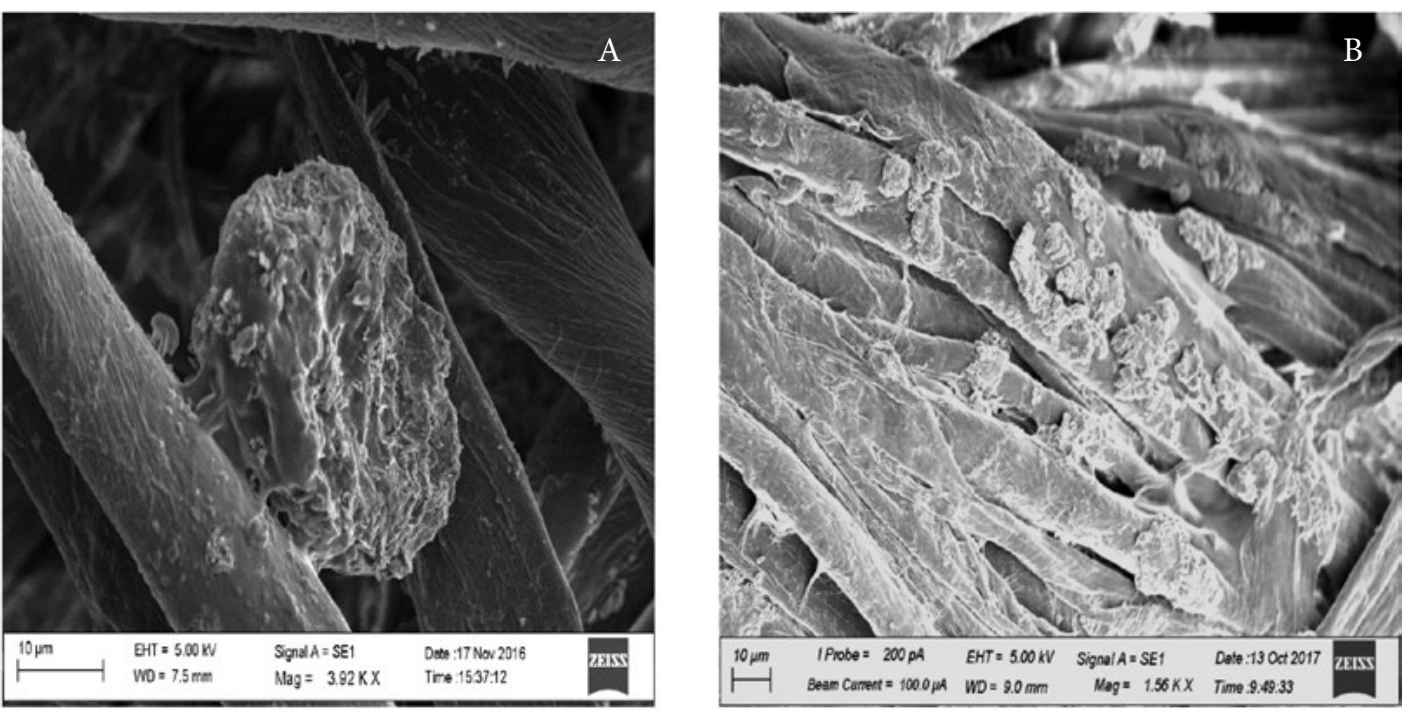

Figure 8. A - SEM images of lime oil microcapsule incorporated textile before washing ( $\times 3.92 \mathrm{~K}$ magnification) B- SEM images of lime oil microcapsules incorporated textile before washing $(\times 1.56 \mathrm{~K}$ magnification $)$ 
aqueous solution of $0.3 \%$ microcapsules which was used to dip the cotton fabric.

\section{8. Investigation of Microcapsule Incorporated Cotton Fabric by SEM}

The morphological characterization of the resultant lime oil microcapsule incorporated cotton fabric was carried out using scanning electron microscopy. According to the SEM images, adhesion of lime oil microcapsules to the cotton fiber surface can be confirmed (Figure 8).

Furthermore, it was also observed that the lime oil microcapsules retained on the cotton fabric even after being subjected mechanical washing under a rotational speed of $500 \mathrm{rpm}$ (Figure 9).

\section{9. Investigation of Antibacterial Activity of Microcapsule Incorporated Cotton Fabric}

The fabric incorporated with lime oil microcapsules was subjected to antibacterial studies. The results of these studies are shown in Table 4.

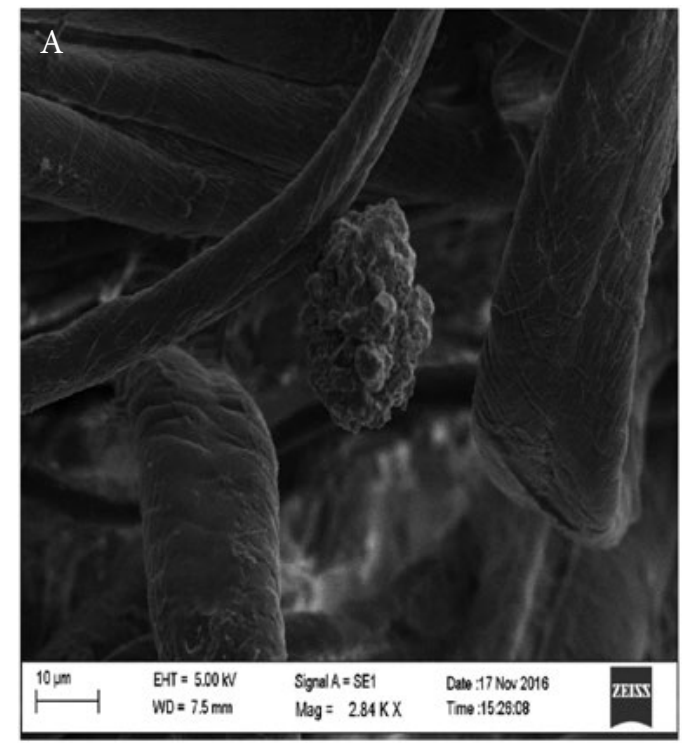

Cotton fabric containing lime oil microcapsules showed clear inhibition zones against all four bacterial strains compared to the cotton fabric disks without the lime oil microcapsules (negative control). The antibacterial activity of cotton fabric significantly increased when the microcapsules on the fabric were subjected to crushing. Therefore, it can be concluded that the lime oil microcapsule incorporated cotton fabric displays significant antibacterial activity against $E$. coli, B. cereus, S. typhimurium and $S$. aureus bacterial species upon breakage of the wall of the microcapsules. Furthermore, the lime oil microcapsule incorporated cotton fabric was subjected to washing under $500 \mathrm{rpm}$ rotational speed for $30 \mathrm{~min}$ to confer the tolerable washing conditions of the microcapsule treated cotton fabric.

According to the results shown in Table 5, inhibition zones were recorded for all four bacterial strains when the microcapsule containing fabric was washed and then subjected to crushing. However, it can be concluded that the lime oil microcapsules that were attached to the fabric were washed out up to a certain extent under the specified wash conditions with a rotational speed of $500 \mathrm{rpm}$.

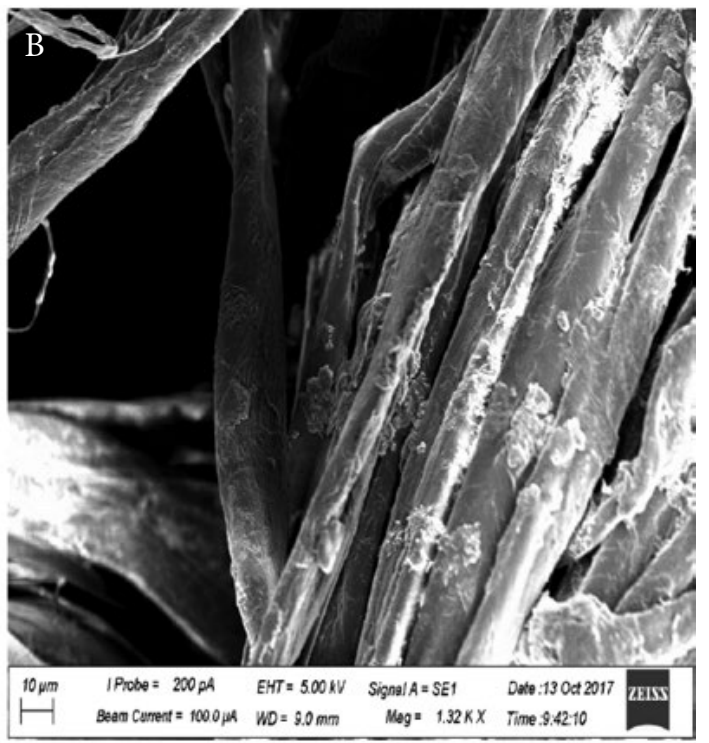

Figure 9. A - SEM images of lime oil microcapsule incorporated textile after washing at $500 \mathrm{rpm}(\times 2.84 \mathrm{~K}$ magnification $) \mathrm{B}-\mathrm{SEM}$ images of lime oil microcapsules incorporated textile after washing at $500 \mathrm{rpm}(\times 1.32 \mathrm{~K}$ magnification)

Table 4. Antibacterial assay results for the lime oil microcapsule incorporated cotton fabric

Bacterial species

Positive control

(Gentamicin) $25 \mu \mathrm{L} / \mathrm{mL}$
Diameter of the inhibition zone ( $\mathrm{mm})$ Negative control $^{*}$
LO incorporated cotton fabric

Fabric with intact microcapsules
Fabric subjected to mechanical crushing

\begin{tabular}{|c|c|c|c|c|}
\hline E. coli & $16 \pm 0$ & NI & $7 \pm 0$ & $10 \pm 0$ \\
\hline B. cereus & $20 \pm 0$ & NI & $8 \pm 0$ & $14 \pm 1$ \\
\hline S. typhimurium & $16 \pm 0$ & NI & $7 \pm 0$ & $10 \pm 0$ \\
\hline S. aureus & $21 \pm 0$ & NI & $7 \pm 0$ & $11 \pm 0$ \\
\hline
\end{tabular}

\# Cotton fabric without lime oil microcapsules $\mathrm{NI}=$ No inhibition 
Table 5. Antibacterial activity of the microcapsule incorporated cotton fabric after subjecting to washing conditions

\begin{tabular}{lcc}
\hline Bacterial species & $\begin{array}{c}\text { Diameter of the inhibition zones (mm) } \\
\text { 500 rpm rotational speed } \\
\text { After crushing }\end{array}$ \\
\hline E. coli & NI & $8 \pm 0$ \\
B. cereus & NI & $8 \pm 1$ \\
S. typhimurium & NI & $7 \pm 0$ \\
S. aureus & NI & $7 \pm 1$ \\
\hline
\end{tabular}

$\mathrm{NI}=$ No inhibition

Three main features of the microcapsule incorporated cotton fabric could be illustrated according to the overall results of this study. However, to improve the retention of microcapsules on the cotton fabric upon washing, a stronger fabric binder can be used during the incorporation of lime oil microcapsules to the fabric.

\section{Conclusion}

Lime oil microcapsules were successfully prepared via the complex coacervation method using gum arabic and chitosan wall materials. The antioxidant activity and the antibacterial activity of lime oil were preserved upon microencapsulation. The synthesized lime oil microcapsules displayed antibacterial activity against all the four tested bacterial species. Additionally, the cytotoxic activity of unencapsulated lime oil was masked upon microencapsulation. The synthesized lime oil microcapsules were successfully incorporated in to the cotton fabric using succinic acid as the binder. The lime oil incorporated cotton fabric displayed significant antibacterial activity upon mechanical crushing of its microcapsules. The lime oil microcapsules incorporated fabric retained its microcapsules and antibacterial activity even after a mild washing step.

\section{References}

1. S. Y. Cheng, M. C. W. Yuen, C. W. Kan, K. L. Cheuk, C. H. Chui, K. H. Lam, Int J Mol med. 2009, 24, 411-419.

2. M. Leskovšek, G. Jedrinović, U. S. Elesini, Acta Chim. Slov. 2004, 51, 699-715.

3. F. M. Bezerra, O. G. Carmona, C. G. Carmona, M. J. Lis, F. F. Moraes, Cellulose. 2016, 23(2), 1459-1470.

DOI:10.1007/s10570-016-0882-5

4. M. Stoppa, A. Chiolerio, Sensors 2014, 14, 11957-11992. DOI:10.3390/s140711957

5. S. Y.Cheng, C. W. M. Yuen, C. W. Kan, K. K. L. Cheuk, RJTA. 2008, 12(4), 41-51.

6. A. Jamekhorshid, S. M. Sadrameli, M. Farid, Renew. Sustain. Energy Rev. 2014, 31, 531-542.

DOI:10.1016/j.rser.2013.12.033
7. F. Ozyıldız, S. Karagonlu, G. Basal, A. Uzel, O. Bayraktar, Lett Appl Microbiol. 2012, 56, 168-179.

DOI:10.1111/lam.12028

8. N. V. N. Jyothi, P. M. Prasanna, S. N. Sakarkar, K. S. Prabha, P. S. Ramaiah, G. Y Srawan. J. Microencapsul, 2010, 27(3), 187-197. DOI:10.3109/02652040903131301

9. S. Khushboo, M. D. Ela, IOSR-JPTE, 2015, 2(2), 1-4.

10. Y. L, X. Zhang, S. Abbas, E. Karangwa, J Food Eng, 2012, 111, 225-233

11. M. A. Teixeira, O. Rodriguez, S. Rodrigues, I. Martins, A. E. Rodrigues. AIChE J, 2012, 58, 1939-1950.

DOI:10.1002/aic.12715

12. G. Nelson, Int. J. Pharm, 2002, 242, 55 - 62. DOI:10.1016/S0378-5173(02)00141-2

13. B. Golja, B. Sumiga, P. F. Tavcer. J Color. Technol, 2013, 129, 338-346. DOI:10.1111/cote. 12044

14. L. J. Reddy, R. D. Jalli, B. Jose, S. Gopu. AJBPR, 2012, 2, 346354

15. R. Gobato, A. Gobato, D. F. G. Fedrigo. Parana J Sci Educ, 2015, 1, 1-10.

16. S. Mahmud, M. Saleem, S. Siddique, R. Ahmed, R. Khanum, Z. Perveen. J. Saudi Chem. Soc, 2009, 13, 195-198 DOI:10.1016/j.jscs.2009.03.001

17. M. C. Colecio-Juárez, R. E. Rubio-Núñez, J. E. Botello-Álvarez, G. M. Martínez-González1, J. L. Navarrete-Bolaños, H. Jiménez-Islas. Chil J Agr, 2012, 72(2), 275-280.

18. D. Hamdan, M. Z. E-Readi, E. Nibret, F. Sporer, N. Farrag, A. E-Shazly, M. Wink. Pharmazie, 2010, 65, 141-147.

19. T.A.Lazalle, Method and composition to infuse an active ingredient into clothes and use of binder agent for microcapsules of said composition, EP Patent Number 2682454A1, date of patent January 8, 2014.

20. Amid, M. Manap, Y. Zohdi, N. K. Molecules, 2014, 19, 37313743. DOI:10.3390/molecules 19033731

21. Soliman, E. A. El-moghazy, A. Y. El-din, M. S. M.; Massoud, M. A. Journal of encasulation and adsorption studies 2013, $48-55$.

22. Patrick, K. E. Abbas, S. Ntsama, I. S. B. Zhang, X. Pak. J. Food Sci, 2013, 23 (1), 17-25.

23. Teklani, P.; Perera, B. G. K. Int j Res Pharm Sci, 2016, 6 (1), 30-35.

24. Agbor, G. A. Vinson, J. A. Donnelly, P. E. Int J Food Sci Nutr Diet, 2014, 3(8), 147-156. 
25. H. Espinosa-Andrews, J. G. Baez-Gonzalez, F. Cruz-Sosa, E. J. Vernon-Carter. Biomacromolecules, 2007, 8, 1313-1318

DOI:10.1021/bm0611634
26. Dutta, P. K. Dutta, J. Tripathi,V. S. J Sci Ind Res, 2004, 63, pp $20-31$

27. Hamid, K. Sultana, S. Urmi, K. F. Ullahc, M. O. Zulfiker, A. H. Hossain, Jordan, A. Int. J. Biol. Sci, 2011, 4 (1), 51-54.

\section{Povzetek}

V pričujoči študiji smo se osredotočili na uporabo tehnike mikrokapsulacije za pripravo antioksidantne in antibakterijske aktivne "pametne" bombažne tkanine, ki vsebuje enkapsulirano olje limete (LO). Mikrokapsule z oljem limete so bile pripravljene s kompleksno koacervacijsko metodo z uporabo hitozana in gumi arabike kot materialov za stene kapsul. Z metodama UV-VIS in FTIR spektroskopije smo preverili uspešno enkapsulacijo olja limete. Sintetizirane mikrokapsule z oljem limete so nepravilnih oblik in se glede na optične in SEM slike razlikujejo po velikosti (15-160 $\mu \mathrm{m})$. Ugotovljeno je bilo, da je nalaganje mikrokapsul znašalo $2943 \pm 128 \mu \mathrm{L} / \mathrm{g} \mathrm{z}$ učinkovitostjo nalaganja $82 \pm 4 \%$. Antioksidativna aktivnost mikrokapsul z oljem limete je bila $1336 \pm 17 \mu \mathrm{g}$ PGE/g (test Folin-Ciocalteu). Analiza smrtnosti solinskih rakcev kaže, da je bila citotoksičnost olja limete minimalizirana $\mathrm{z}$ mikrokapsulacijo. Sukcinsko kislino smo uporabili kot vezivo za pritrditev mikrokapsul z oljem limete na bombažno tkanino. Slike SEM so potrdile stabilno pritrditev mikrokapsul na bombažna vlakna. Bombažna tkanina, ki vsebuje mikrokapsule $\mathrm{z}$ oljem limete, je pokazala pomembno protibakterijsko aktivnost napram štirim vrstam bakterij tako pred kot tudi po pranju. 